\title{
LIETUVOS ETNOLOGIJA (Lithuanian Ethnology)
}

It is one of two periodical publications of the Department of Ethnology of the Lithuanian Institute of History. Etnologiniai tyrinejimai Lietuvoje (Ethnological Studies in Lithuania) publishes the materials of the conferences, held by the Department. Lietuvos etnologija (ISSN 1392-4028) is a series of monographs and larger studies. In the years of the Soviet regime the very word 'ethnology' was treated with suspicion. Nevertheless, despite the pressure of the occupational authorities, ethnological research was conducted, though special monographs and series were not put out. Until 1989 quite a number of them were published in the general historical series $I \check{s}$ lietuviu kultüros istorijos (From the History of Lithuanian Culture) or in separate editions. When Lithuania regained its independence there appeared better possibilities to widen the scope of the ethnological research and publish its results. In 1996 a specialist series was set up.

The first volume of Lietuvos etnologija comprises the monograph of Žilvytis Bernardas Šaknys Jaunimo brandos apeigos Lietuvoje XIX a. pabaigoje - XX a. pirmojoje puseje (Youth Initiation Rites in Lithuania in the Late-Nineteenth and the First Half of the Twentieth Centuries). Vilnius: Pradai, 1996; pp. 216. For a review of this work, see Lithuanian Historical Studies, vol. 2, 1997, 189-191.

The second volume, Amatas ir küryba (Craft and Creation) by Vacys Milius, Janina Morkūnienė and Irma Šidiškienè (Vilnius: Pradai; pp. 316), appeared in 1997. It comprises three studies, each of about 100 pages. The first is Žemaitijos vandens malūnai (WaterMills of Žemaitija) by V. Milius; it consists of an introduction, ten chapters and conclusions. The essay contains a comprehensive analysis of the interior and exterior of the mill, of corn grinding and social relations having to do with this activity.

The second study is Kailiu išdirbimas Lietuvoje XIX a. antrojoje puseje ir XX a. pirmojoje puseje (Fur Processing in Lithuania in the Second Half of the Nineteenth and the First Half of the Twentieth Centuries) by J. Morkūniene. In addition to the historical review of this craft and the description of its technologies, the paper 
presents an analysis of apprenticeship, of the workshops and tools; attention is also paid to the peculiarities depending om the region and the nationality of the furriers.

One more study in this volume is Tautiniai drabužiai lietuviu kultūroje (XIX a. pabaiga-XX a. 4 dešimtm.) (National Costumes in Lithuanian Culture: end of the 19th cent. - the fourth decade of the 20th cent.) by I. Šidiškienè. The paper analyzes the spread of the national costumes, influenced by the intelligentsia, alongside the standard fashionable attire. The study comprises many drawings, graphs and photographs.

In 1998 the third volume of Lietuvos etnologija was issued by Irena Regina Merkienè and Marija Pautieniūtè-Banionienè under the title Lietuvininku pirštinès. Kultūru kryžkelèje / Gloves of the People of Lithuania Minor. At the Crossroads of Cultures (Vilnius: Žara; pp. 212). In contrast to previous volumes the text of the third is presented in both Lithuanian and English. The publication consists of two studies. The first is Lietuvininku pirštinès. Lokaline kultūra Europos kontekste /Gloves in Lithuania Minor. Local Culture in the European Context by R. Merkienè. The study consists of an introduction, two chapters and conclusions. The author argues that prehistorical, Gothic, Renaissance Western, Eastern and Central European patterns, which reached our days, were revitalized in Lithuania Minor in the twentieth century. Their novelty is observed in individual and local compositional ornaments. The statements of the study are substantiated by fourteen tables, thirty photographs and drawings (among them sixteen are coloured) and two maps.

The other study of this volume is Moteru rankdarbiai Klaipedos krašte. Pirštinès / Women's Handiwork in the Area of Klaipeda. Gloves by M. Pautieniūtè-Banionienè. The essay, dealing with the shapes, patterns, colours and knitting technique of gloves, consists of six chapters, lists of the participants of the Lithuanian Folk Art Exhibition of East Prussia, held in Berlin in 1908, and of the exhibits; it also contains 103 photographs and charts.

In 1998 there also appeared the fourth volume - Audiniai kaimo kultūroje. (Fabrics in Rural Culture) by Vida Savoniakaitè (Vilnius: Alma littera; pp. 248). The study, consisting of an introduction, five chapters and conclusions, is devoted to the analysis of geometric patterns in Lithuanian fabrics. In her work the author reveals the work of Lithuanian town and countryside weavers, their interpretation of the fabric and the way they modify the age-old patterns. In the course of history there appeared specific geometric fabric patterns, their names, perception and use in Lithuania. In the analysis of fabric ornamentation the author relies on her own method. The work 
is lavishly illustrated with coloured and black-and-white pictures, drawings and graphs.

The fifth volume of Lietuvos etnologija was published also in 1998. It is represented by the monograph of Petras Kalnius Etniniai procesai Pietryčiu Lietuvoje XX a. antrojoje puseje (Ethnic Processes in South-Eastern Lithuania in the Second Half of the Twentieth Century).Vilnius: Žara; pp. 224. It consists of an introduction, three chapters and conclusions; the author's arguments are illustrated by forty tables. It is the first monograph comprehensively revealing the role of ethnically mixed families in the assimilative processes of the population in South-Eastern Lithuania (districts of Šalčininkai, Trakai, Vilnius and Švenčionys). This study substantially corroborates the theories of sociologists, historians and linguists, who have not paid proper attention to the phenomenon under review. Kalnius' work also discloses the aftermath of the forceful Soviet Russification and Polonization in the natural assimilation of the population in the region and the new tendencies of the ethnic processes after the re-establishment of Lithuanian independence as well as the phenomena of internal consolidation and cultural and social integration of various nationalities into Lithuanian society.

Volume 6 of the series is the monograph of Dr. Rasa Paukštytė Gimtuvès ir krikštynos Lietuvos kaimo gyvenime (XIX a. pab. $-X X$ a. pirmoje puseje) (Birth and Baptism in Lithuanian Village Life. End of the 19th - the First Half of the 20th Centuries). Vilnius: Diemedis, 1999. For the first time in Lithuanian ethnology the author examines those customs in the context of the rural life in nearly two hundred pages. The study is based on copious sources and a lot of fieldwork. Iconographic materials and maps are a useful contribution to the book.

The chief editor of the series is Irena Regina Merkiené, and the members of the editorial board are Romualdas Apanavičius, Petras Kalnius, Leonardas Sauka and Antanas Tyla.

Each volume of Lietuviu etnologija contains extensive summaries, lists of maps and illustrations in English, bibliographies and indexes.

At the present time two more volumes are to be published and two more are being edited currently. 
The following publications of the Lithuanian Institute of History are available from the Institute bookshop

In English:

Lithuanian Historical Studies. Vol. 2, 1997, Vol. 3, 1998, Vol. 4, 1999. Archaeologia Baltica. Vol. 1, 1994; Vol. 2, 1996; Vol. 3, 1997. Zigmantas Kiaupa, Jūratė Kiaupienė, Albinas Kuncevičius. The History of Lithuania before 1795. 2000.

In Lithuanian (mostly with summaries in English):

Lietuvos istorijos metraštis. 1992 metai

(The Yearbook of the History of Lithuania. 1992), 1994;

1993 metai, 1994; 1994 metai, 1995; 1995 metai, 1996;

1996 metai, 1997; 1997 metai, 1998; 1998 metai, 1999.

Lietuvos Metrika. Knyga 8 (Lithuanian Metrica. Book 8), 1994;

Knyga 7 (Book 7), 1995; Knyga 10 (Book 10), 1996;

Knyga 11 (Book 11), 1996; Knyga 1 (Book 1), 1998;

Knyga 25 (Book 25), 1998; Knyga 3 (Book 3), 1999;

Knyga 530 (Book 530), 1999.

Vygandas Marburgietis. Naujoji Prūsijos kronika (Chronicon seu Annales Wigandi Marburgensis), 1999.

Artūras Dubonis. Lietuvos didžiojo kunigaikščio leičiai ('Leitis' of the Grand Duke of Lithuania: From the History of the Early State Structures of Lithuania), 1997.

Egidijus Banionis. Lietuvos didžiosios kunigaikštystès pasiuntinybiu tarnyba $X V-X V I$ amžiais (Envoy Service of the Grand Duchy of Lithuania in the 15th and 16th Centuries), 1998.

Virgilijus Pugačiauskas. Napoleono administracija Lietuvoje (Napoleon's Administration in Lithuania), 1998.

Dalia Marcinkevičienè. Vedusiujų visuomenė: santuoka ir skyrybos Lietuvoje XIX amžiuje - XX amžiaus pradžioje (Society of Married People: Marriage and Divorce in Lithuania in the 19th and at the beginning of the 20th centuries), 1999. 
Gediminas Vaskela. Žemès reforma Lietuvoje 1919-1940

(Land Reform in Lithuania Between 1919 and 1940), 1998.

Edvardas Gudavičius. Mindaugas. 1998.

Gintautas Zabiela. Lietuvos medinès pilys

(Wooden Castles in Lithuania), 1995.

Vytautas Kazakevičius. IX-XIII a. baltu kalavijai

(Baltic Swords of the 9th-13th Centuries), 1996.

Vykintas Vaitkevičius. Senovès Lietuvos šventvietès. Žemaitija (Sacred Sites of Lithuania. Samogitia), 1997.

Audronė Bliujienè. Vikingц epochos kuršiu papuošalu ornamentika (Style and Motifs of Couronian Ornaments in the Viking Age), 1999.

Lietuvos etnologija (Lithuanian Ethnology, a series), vols. 3-6.

Enquiries and orders should be addressed to:

Publishing Department

Lietuvos istorijos institutas

Kražių 5

LT-2001 Vilnius

Lithuania

Tel.: 3702224438 / 610143

Fax: 3702611433

E-mail: istorija@comliet.lt 